\title{
OLIVEIRA, JÚLIO CÉSAR MAGALHÃES DE. POTESTAS POPULI. PARTICIAPATION POPULAIRE ET ACTION CCOLLECTIVE DANS LES VILLES DE L'AFRIQUE ROMAINE TARDIVE (VERS 300-430 APR. J.- C.), TURNHOUT, BREPOLS, 2012, PP.375'.
}

Fabiano Fernandes ${ }^{2}$

The book is an important contribution to the development of the "History from below", and results from Oliveira's PhD thesis presented in 2005 at the Universite de Paris Ouest Nanterre, published in 2012. Against general expectations in relation to research on Late Antiquity, the author presents a systematic discussion of the Corpus Augustinianum in which he identifies the forms of pressure and political actions of the plebs during the late Roman period. The accurate analysis of the different meanings of words used by Augustine in his letters and sermons is conducted with methodological precision and rigor.

The introduction of the book presents the historiographic perspective adopted by the Oliveira and some of the main concepts used in his work. He explains that the theme of the role of the plebs in history has received a growing attention of recent research on Ancient Roman history, but the political action of the plebs has been often regarded as mere reaction to a specific critical context, or as a result of conditions derived by the relations with patrons. He says that the originality of his work lies precisely in the fact that in order to reach a broader understanding of the participation of the plebs in social and ecclesiastical life in the cities it is necessary to take into consideration both institutional and non-institutional actions and aspects of their presence action. According to this view, it would be possible to find evidence that the actions of the urban plebs in North Africa would be a result of a series of combined strategies rather than an irrational reaction to critical moments.

\footnotetext{
${ }^{1}$ Translated by Patrícia de Freitas Camargo.

2 Associate Professor. Federal University of São Paulo - São Paulo, MG, Brasil. e-mail: fabiano.fernandes@unifesp.br
} 
In the first part of the work, entitled Les expériences constitutives de la vie plébéinne, the author inquires into a variety of sources, such as administrative acts, letters of Augustine, material culture and archeological sources, in order to understand the experience of the life of the plebs. He presents a substantial discussion about the meaning of the term plebs and compares systematically the forms of settlement of urban workshops, giving particular attention to work conditions and sociability. The author emphasizes the study of the lower stratum of Roman society in its late period, carefully collecting all information available from the sources. He studies particularly the relations of sociability and their consequences in terms of political action, to which he dedicates a section entitled Les réseaux de sociabilité. In this section, the author's main concern is the perception of the role of formal and informal links in the origin of collective actions, which were often taken into consideration by the dominant social groups in their governing strategies.

The second part of the work, entitled La plèbe chrétienne et les élections ecclésiastiques, is dedicated to case studies in many North-African cities. The core of this second part is the study of the active role of the plebs in ecclesial elections and in the establishment of an intransigent policy for the repression of paganism. The author studies the elections in Cirta, Hippo, Cherchell (Caesarea), among others. He explores the vigor of the establishment of Christianity in the Roman province of Mauritania Caesariana and its development, considering the role of Christian religious dissidence in the background of disputes around the election of bishops. Conflicts in the community of Caesarea were described as "foule séditieuse considérable une seditiosa plurima multitudo, constituée en grande partie par des 'pauvres gens'" (2012 : 214); this means that the pauperes - which constituted the major part of the community, including part of the plebs and workers were not mere spectators assisted by the Church: they aimed at playing an active role in the conduction of the affairs of the Church in North-Africa.

In the third part of the work, entitled Conflits et violences urbaines, the author inquires on the iconoclasts of Calama and Hippo, among other conflicts. The social-religious questions are unfolded through the study of particular cases, such as the question of the statue of Hercules and the demonstrations of June 401 in Carthage. These demonstrations arise from the conversion of Faustinus, a rich pagan argentarius who was a declared enemy of the Christian community. This conversion was regarded with distrust by part of the plebs, for it was supposedly motivated by mere interest. According to the author, the letters of Augustine related to this conflict are dated with precision, with intervals of few months. Oliveira notes that Faustinus resisted to the conversion because he was concerned about the possible mistrust of the urban plebs in case they regarded it as a strategy to gain social prestige and power over the Christian community. The argument is taken in part from Augustine, but the author re-shapes it, providing consistent evidence to support it and to foreground the active role of a 
significant part of the plebs in political and religious affairs. The author says that, En effet, c'est précisément parce que la voix du peuple était vue comme la manifestation de la volonté de Dieu et l'expression de l'opinion publique, que les autorités civiles ou ecclésiastiques ne pouvaient pas contester sa légitimité, même lorsque le peuple s'attribuait un rôle bien plus actif que celui que ses dirigeants acceptaient de lui concéder (2012: 248). Therefore, the pressure of the plebs was not restricted to moments of crisis, but it was an important factor taken into consideration by the dominant group in moments of decision in its institutional or non-institutional forms. As seen in the author's words, violence was a form of continuity of political debate through the use of different means, which include the violence of the plebs in political conflicts (2012: 274). The protests of the plebs were not restricted to religious questions; they were a regular form of dissent against economical hardship, social oppression, or against the authorities of the city. Nevertheless, the main sources for the study of North Africa in the $4^{\text {th }}$ and $5^{\text {th }}$ centuries were ecclesiastic documents. For example, Oliveira analyses in one of the sections of the third part of his work the interesting case of a soldier or royal official who was murdered between 409 and 412 for excessive exaction, which record was due mainly to fact that the man in question was dragged out from the church where he searched for shelter, and to the fact that the bishop was accused of omission by the Christian community of Hippo, because he did not take any action in favor of the people who felt offended by the exaction. The author concludes that violent claims were part of the dialog between the plebs and city authorities, even when actual revolts did not take place.

Despite the fact that the urban plebs were subject to an autocratic imperial government, to an aristocratic city government, and to the growing power of the Church, these instances of power could not impede the action and participation of the plebs, or of part of them, in many contexts as political actors with a significant independence. Oliveira's arguments are well-articulated and convincing, and the book deserves a translation into Portuguese as soon as possible. 
